\title{
GENOTOXIN EFFECT OF COMPOSITE RESIN
}

\author{
Tienneke Riana Septiwidyati ${ }^{1}$, Elza Ibrahim Auerkari ${ }^{2}$ \\ 1. Program Magister Oral Biologi, Fakultas Kedokteran Gigi, Universitas Indonesia \\ 2. Departemen Oral Biologi, Fakultas Kedokteran Gigi, Universitas Indonesia \\ *Penulis korespondensi:eiauerkari@yahoo.com
}

\begin{abstract}
At this moment composite resin is the most widely used material for dental restoration. The contents of the resin is a mixture of monomer bisphenol A glycidyl methcrylate (Bis-GMA), triethylene glycol dimethylmethacrylate (TEGDMA) and urethane dimethacrylate (UDMA) and special particle fillers made of radioopaque glass. Many studies have been conducted to study the biocompatibility of composite resin, especially the cytotoxicity and genotoxicity test. Genotoxicity tests that are often carried out are comet test for DNA damage protection and micronuclei test for protection of genome damage. The monomer content of composite resins can have a genotoxic effect.
\end{abstract}

Keyword: Genotoxin Effect, Composite Resin

\section{ABSTRAK}

Pada saat ini resin komposit merupakan bahan yang paling banyak digunakan untuk restorasi gigi. Kandungan dari resin komposit merupakan campuran dari monomer bisphenol A glycidyl methcrylate (Bis-GMA), triethylene glycol dimethylmethacrylate (TEGDMA) dan urethane dimethacrylate (UDMA) dan partikel filler khusus yang terbuat dari glass radioopak. Banyak penelitian yang sudah dilakukan untuk mengetahui biokompatibilitas dari resin komposit, terutama uji sitotoksisitas dan genotoksisitas. Uji genotoksisitas yang sering dilakukan adalah uji komet untuk mendeteksi kerusakan DNA dan uji micronuclei untuk mendeteksi kerusakan genom. Kandungan monomer dari resin komposit dapat memberikan efek genotoksik.

Kata Kunci: Efek Genotoksin, Resin Komposit

\section{PENDAHULUAN}

Bahan restorasi yang banyak digunakan saat ini adalah dental resin komposit. Resin komposit terdiri dari monomer dan filler. Monomer dikonversi menjadi polimer sehingga menjadi bentuk padat, sedangkan filler digunakan sebagai material penguat. Matriks monomer dan filler disatukan menggunakan coupling agent seperti titanates dan zirconates. Komposit terdiri dari tipe konvensional, hybrid,nanohybrid, packable hybrid, flowable hybrid, microfilled homogen, microfilled heterogen, nanofilled, dan buckfill.
Genotoksisitas merupakan kemampuan bahan kimia untuk merusak informasi genetik di dalam sel sehingga mengakibatkan mutasi sel. Efek genotoksik terdiri dari titik mutasi sepanjang rantai DNA, kerusakan struktur keseluruhan DNA, atau kerusakan pada struktur kromosom yang mengandung DNA yang dituju. Berbagai tes telah dikembangkan untuk menentukan apakah kerusakan telah terjadi pada tingkat genetik. Beberapa diantaranya adalah tes komet dan micronucleus assay. Tes komet digunakan untuk mengukur kerusakan DNA baik dalam bentuk 
single strand break atau double strand break. Sedangkan, micronucleus assay digunakan untuk mendeteksi kerusakan genom, karena misrepair, sehingga mengakibatkan pada struktur kromosom yang berakibat pada pembentukan fragmen acentrik atau tetap tidak diperbaiki dalam bentuk kromosom yang terpecah.

Beberapa penelitian telah dilakukan untuk mengetahui efek genotoksik pada mukosa oral akibat dari bahan restorasi resin komposit. Menurut penelitian, monomer pada resin komposit dapat menyebabkan efek sitotoksik dan genotoksik pada konsentrasi yang relevan yang dilepaskan di rongga mulut. Monomer diidentifikasi berperan untuk peningkatan intraselular spesies oksigen reaktif dan penurunan konsentrasi glutasi sehingga menyebabkan kerusakan pada DNA.

\section{Dental Resin Komposit}

Material dental komposit terdiri dari dua fase berbeda, yaitu matriks resin yang polimerasi ke bentuk padat dan partikel filler penguat. Matriks resin terdiri dari monomer dengan beban molekul rendah, yang dikonversi menjadi polimer dengan beban molekul besar ketika material filling terekspos cahaya dengan suatu panjang gelombang spesifik (427-429 $\mathrm{nm}$ ). Banyak resin komposit merupakan campuran dari aromatic dan aliphatic dimethacrylate monomers like bisphenol A glycidyl methcrylate (Bis-GMA), triethylene glycol dimethylmethacrylate (TEGDMA) dan urethane dimethacrylate
(UDMA) dan partikel filler terbuat dari glass, mineral, dan resin. Matriks dan filler disatukan menggunakan coupling agent seperti titanates dan zirconates.[1], [2]

Klasifikasi dari komposit resin terdiri dari tipe konvensional dengan partikel besar yang digunakan pada restorasi area yang mendapat tekanan tinggi. Tipe hybrid terdiri dari tiga ukuran partikel yaitu partikel besar, sedang, dan kecil. Tipe hybrid partikel besar ditujukan untuk restorasi area yang mendapat tekanan tinggi dan butuh pemolesan seperti pada kelas I, II, III, dan IV. Tipe hybrid partikel sedang digunakan untuk restorasi area yang mendapat tekanan tinggi dan butuh pemolesan seperti pada kelas III dan IV. Tipe hybrid partikel kecil dan tipe nanohybrid digunakan untuk restorasi area yang mendapat tekanan sedang dan butuh pemolesan seperti pada kelas III dan IV. Komposit packable hybrid digunakan sebagai restorasi pada area yang memerlukan kondensasi seperti pada kelas I dan II. Komposit flowable hybrid digunakan sebagai restorasi pada area yang memerlukan aliran komposit dan / atau mencapai akses yang sulit seperti pada kelas II. Komposit microfilled homogen digunakan untuk restorasi pada area yang mendapatkan tekanan rendah dan subgingiva yang membutuhkan kilau dan poles yang tinggi. Komposit microfilled heterogen digunakan untuk restorasi pada area yang mendapatkan tekanan rendah dan subgingiva dimana butuh sedikit penyusutan. Komposit nanofilled ditujukan untuk restorasi pada area anterior dan posterior yang tidak 
kontak. Komposit bulkfill digunakan untuk restorasi direct anterior dan posterior, lapisan dibawah restorasi direct, core build-ups, splinting, restorasi indirect (inlay, onlay, veneer), restorasi gigi sulung, fissure sealent pada gigi geraham dan premolar, perbaikan pada restorasi porselen, enamel, dan mahkota sementara. [2],[3]

Sekarang ini, komposit yang termasuk sering digunakan adalah komposit nanofill. Komposit nanofilled / nano komposit merupakan komposit yang memiliki ukuran partikel yang sama dengan komposit microfilled, tapi partikelnya telah mengalami perubahan permukaan sebelum diaglomersi menjadi bentuk 3 dimensi yang lebih besar. Sebaliknya, tipe tersebut membentuk isolat dan/ atau lossely bound aglomerat spheroidal (cluster) dari nanopartikel primer. Perlakuan permukaan memungkinkan peningkatan pembebanan filler dengan mengurangi viskositas yang berkembang ketika partikel ditambahkan ke monomer. Ukuran cluster bisa melebihi $100 \mathrm{~nm}$. Semua nanokomposit yang saat ini dipasarkan memiliki ukuran partikel primer rata-rata dalam kisaran 40-nm dan begitu juga dengan ukuran yang sama seperti komposit mikrofil.[2]

\section{Genotoksisitas}

Genotoksisitas adalah kemampuan bahan kimia untuk merusak informasi genetik di dalam sel sehingga mengakibatkan mutasi. Substansi genotoksik menginduksi kerusakan materi genetik dalam sel melalui interaksi dengan sekuens dan struktur DNA. Semua bahan kimia mutagenik bersifat genotoksik; namun, tidak semua senyawa genotoksik bersifat mutagenik.[4]

Efek genotoksik terdiri dari titik mutasi sepanjang untai DNA, kerusakan struktur keseluruhan DNA, atau kerusakan pada struktur kromosom (yang mengandung DNA). Berbagai tes telah dikembangkan untuk menentukan apakah kerusakan telah terjadi pada salah satu dari ini tingkat. Tes yang paling sering dilakukan untuk mutagenesis adalah Ames tes, untuk mendeteksi titik mutasi dengan menggunakan beberapa untai DNA dari bakteria Salmonella typhimurium, yang telah dipilih untuk sensitif kepada mutagen. Mouse Lymphoma dan HGPRT assay merupakan prosedur yang biasa digunakan pada sel mamalia untuk mendeteksi titik mutasi. Mouse Lymphoma assay juga dapat untuk mendeteksi lesi clastogenik pada gen (kerusakan kromosom). Uji untuk kerusakan dan perbaikan DNA termasuk in vitro dan in vivo Unscheduled DNA Synthesis (UDS). Uji sitogenetik dapat digunakan untuk mengobservasi langsung kerusakan kromosom. Terdapat metode in vivo dan in vitro termasuk uji Aberasi Kromosom dan Mouse Micronucleus assays.[5]

ISO 10993-1 menetapkan penilaian potensi genotoksik untuk material yang permanen dan memiliki kontak lama (> 24 jam) dengan jaringan internal dan darah. Material pada extracorporeal dengan kontak terbatas $(<24$ jam) mungkin memerlukan evaluasi genotoksisitas. Umumnya, material dengan eksposur 
lama membutuhkan tes Ames dan dua metode in vivo, biasanya dengan Aberasi Kromosom dan Mouse Micronucleus. Material yang kontak tubuh dapat diuji hanya dengan menggunakan uji Ames. [5]

Kerusakan DNA juga dapat dideteksi dengan menggunakan Comet Assay / Single Cell Gel Electrophoresis (SCGE). Tes ini dapat digunakan untuk mengukur kerusakan DNA baik dalam bentuk single strand break (SSB) atau double strand breaks (DBS). Pada saat elektroforesis, DNA yang terdenaturasi bermigrasi keluar inti sel berdasarkan besar fragmennya. Elektroforesis adalah teknik pemisahan molekul dan komponen bermuatan berdasakan perbedaan tingkat migrasinya pada media gel agarose. Di atas preparat mikroskop dilakukan penanamkan sel pada selapis tipis LMA (low melting agarose), kemudian dilakukan pelilisan sel dengan menggunakan larutan detergen dan garam konsentrasi tinggi (cold lysis solution seperti NaCL, EDTA, Tris$\mathrm{HCl}$, triton $\mathrm{X}-100)$.[6]

Saat berada pada larutan alkali di elektroforesis, DNA mengandung gugus fosfat bermuatan listrik negatif, hal ini menyebabkan area rantai ganda DNA mengalami pengenduran dan mengandung DSB sehingga akan bermigrasi ke kutub positif (anoda). Ekor komet terbentuk akibat migrasi tersebut, sedangkan kepala komet terbentuk dari daerah yang tidak mengalami pengenduran. Jadi dapat dikatakan DNA yang utuh terdapat pada kepala komet dan DNA yang rusak terdapat pada ekor.[6]

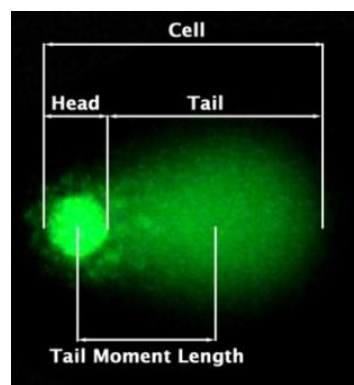

Gambar1, Gambaran Uji Komet [6]

Terdapat dua metode tes komet yaitu metode netral alkali. Metode netral dilakukan menggunakan larutan yang memiliki pH 9,5 pada proses pelisisan sel dan elektroforesis. Kerusakan yang dapat terdeteksi hanya berupa DSB pada DNA, karena nilai $\mathrm{pH} 9,5$ masih berada di bawah ambang batas nilai $\mathrm{pH}$ yang dibutuhkan untuk membuka rantai ganda DNA. Metode alkali menggunakan larutan (300 mM sodium hidroksida dan 1 mM EDTA) yang memiliki nilai $\mathrm{pH}$ $>13$ sehingga double strand DNA dapat terbuka dan SSN dapat terdeteksi. Tahap-tahap tes komet dimulai dengan persiapan preparat, pelisisan sel, proses elektroforesis, netralisasi preparat, pewarnaan dan pengamatan preparat. [6]

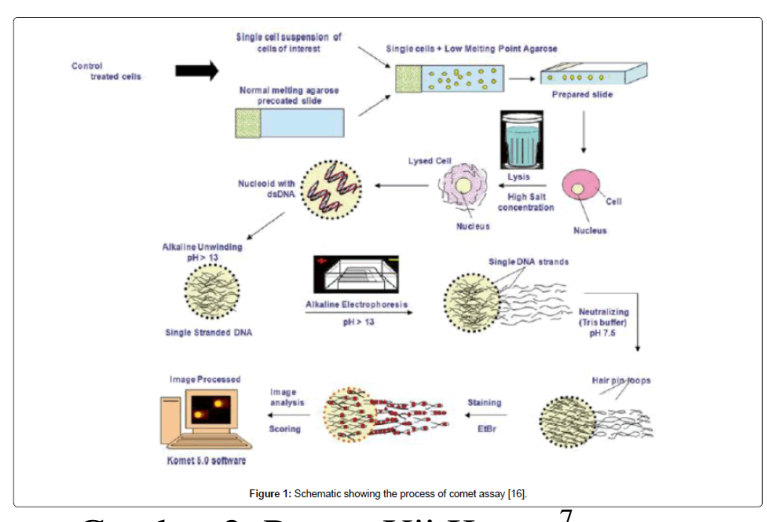

Gambar 2. Proses Uji Komet ${ }^{7}$ 
Selain itu ada micronucleus assay yang mendeteksi kerusakan genom, karena misrepair, mengakibatkan perubahan yang parah pada struktur kromosom yang berakibat pada pembentukan fragmen acentrik atau tetap tidak diperbaiki dalam bentuk kromosom yang terpecah. Uji ini bahkan mendeteksi kerusakan pada spindel mitosis yang menghasilkan lagging kromosom selama anafase dan akhirnya hilang oleh proses mikronukleus. Kehadiran micronuclei menunjukkan ketidakstabilan genom. Pecahnya double strand merupakan titik awal dalam fiksasi kerusakan DNA dalam bentuk penyimpangan kromosom. Pada fase selanjutnya dari pembelahan sel, terjadi beberapa jenis penyimpangan, seperti kromosom terpecah dan terbentuk fragmen acentrik, muncul sebagai mikronuklei.[8]

Agar mikronukleus dapat dihitung, harus memenuhi kondisi berikut: (a) harus terdiri dari nuclear material; (B) itu harus benar-benar dipisahkan dari nukleus orang tua; (c) diameternya harus kurang dari $1 / 3$ dari inti yang terkait; (D) halus, berbentuk oval atau bulat; (e) harus berada pada bidang fokus yang sama dan (f) harus memiliki warna, tekstur, dan refraksi yang sama dengan nukleus utama.[8]

\section{Efek Genotoksisitas Resin Komposit}

Beberapa penelitian telah dilakukan untuk mengetahui efek genotoksisitas pada mukosa oral akibat dari bahan restorasi resin komposit. Berdasarkan penelitian terdahulu monomer dikatakan sebagai senyawa sitotoksik dan sitotoksisitas pada dental komposit dikaitkan dengan pelepasan monomer residu. Beberapa penelitian menunjukkan bahwa molekulmolekul tersebut dapat menyebabkan efek sitotoksik dan genotoksik pada konsentrasi yang relevan dengan dilepaskan di rongga mulut. Monomer diidentifikasi berperan untuk peningkatan intraselular spesies oksigen reaktif dan penurunan konsentrasi glutasi sehingga menyebabkan kerusakan pada DNA.[1]

Ingunn Fredsted dan Idunn Hertzberg melakukan penelitian yang lebih terkini untuk mengetahui efek genotoksik dari resin komposit dental pada sel progenitor epitelium gingival manusia (HPEGs) dengan menggunakan comet assay dengan membandingkan beberapa merek komposit di Norway. Beberapa merek komposit tersebut direndam pada medium sel selama 1,3,7, dan 21 hari. Berdasarkan penelitian mereka, dapat dikatakan bahwa tidak ditemukan komposit yang memiliki efek toksik pada HPEGs yang diuji karena hasil uji komet ditemukan kerusaksan DNA pada ekor komet $<40 \%$ sedangkan dapat dikatakan memiliki efek genotoksik apabila mengalami kerusakan DNA pada ekor komet mendekati 100\%.[1]

Taubock, Marovic, Zeljezic, dkk meneliti potensial genotoksik pada komposit bulk fill dengan menggunakan uji komet dan cytokinesis-blocked micronucleus assay. Hasil dari penelitian ini menunjukkan bahwa tidak ada komposit bulk-fill yang secara 
signifikan mempengaruhi parameter uji komet yang digunakan dalam penilaian kerusakan DNA primer atau menginduksi pembentukan signifikan dari salah satu kelainan kromatin yang dihasilkan.[9]

Tadin, Galic, dan Mladinic meneliti efek genotoksik pada sel gingival pasien dengan restorasi komposit menggunakan uji komet dan mikronukleus. Hasil penelitian ini menunjukkan bahwa penambalan dengan resin komposit menunjukkan efek genotoksik pada sel epitel gingiva. Meskipun analisis statistik menunjukkan peningkatan yang signifikan dalam tingkat kerusakan utama di DNA, dideteksi oleh uji komet dan mikronukleus pada 7 dan 30 hari setelah restorasi. Enam bulan setelah restorasi jumlah mikronuklei kembali ke tingkat basal, menunjukkan kurangnya efek jangka panjang pada stabilitas genom. Berdasarkan hasilnya penelitian ini dapat simpulkan bahwa peningkatan kerusakan DNA bersifat sementara dan mungkin tidak memiliki sifat biologis.[8]

Visalli, Baluca, dan Pietro meneliti efek genotoksik pada oral mukosa dengan uji komet pada pasien dengan tambalan resin komposit. Hasil dari penelitian ini, menunjukkan efek genotoksik secara lokal dan sistemik. Efek sistemik terjadi saat co-monomer yang tidak terpolimerisasi dilepaskan komposit resin dalam rongga mulut dan berdifusi melalui dentin ke dalam ruang pulpa, lalu bermigrasi ke dalam aliran darah dan mencapai hampir semua organ. Efek lokalmya saat terjadi pelepasan metakrilat dari monomer resin komposit akan menyebabkan kerusakan DNA baik secara lokal pada kavitas bukal (pada penelitian tersebut).[10]

\section{Mekanisme Genotoksisitas Resin Komposit}

Substansi genotoksik dilepaskan oleh resin komposit gigi telah diteliti selama dua dekade terakhir. Sebagian besar penelitian berfokus pada efek senyawa resin pada fungsi seluler dasar, seperti proliferasi sel, penghambatan aktivitas enzim, gangguan morfologi sel, integritas membran, metabolisme sel (DNA-, RNA- dan sintesis protein) dan viabilitas sel. Sebagian besar penelitian menunjukkan bahwa resin komposit mampu melepaskan senyawa dengan ganotoksisitas berat (Bis-GMA, UDMA, TEGDMA, DMBZ, кal DMDTA) atau medium (HEMA, BEMA, CQ, DMPT dan DMAPE), sedangkan produk biodegradasinya, seperti asam metakrilat, telah ditunjukkan secara umum mengurangi toksik. Semakin sekarang efek toksik dari senyawa ini berkurang dengan tambahan beberapa bahan. Dari beberapa penelitian dapat dibuat peringkat sitotoksisitas monomer dasar sebagai berikut: BisGMA> UDMA> TEGDMA $\gg>$ HEMA.[11]

\section{TEGDMA (Triethyleneglycol Dimethacrylate)}

TEGDMA mudah dilepaskan dari komposit yang terpolimerisasi ke dalam media berair. TEGDMA adalah pengencer yang umum digunakan pada komposit berbasis resin dan juga komponen umum dari adhesif dentin dalam jumlah yang bervariasi dari 25 hingga $50 \%$. 
Dalam kebanyakan penelitian, konsentrasi TEGDMA berkisar antara 0,5-5 mM. Karena sifat lipofiliknya, TEGDMA dapat dengan mudah menembus sitosol dan selaput lipid membran sel mamalia.[11]

Beberapa produk metabolik TEGDMA, seperti senyawa epoksi 2,3-epoxymethacrylic acid (2,3EMA) telah ditemukan menyebabkan efek sitotoksik.. Di sisi lain, metabolit lain, seperti trietilen glikol (TEG) dan asam metakrilat (MAA) menunjukkan sitotoksisitas minimal. Pada konsentrasi yang lebih rendah, jenis utama kematian sel yang diinduksi oleh TEGDMA adalah apoptosis (kematian sel terprogram), sedangkan nekrosis lebih jelas pada konsentrasi yang lebih tinggi. TEGDMA penginduksi apoptosis ditingkatkan oleh efek penghambatan pada phosphatidylinositol 3-kinase dalam sel-sel pulpa manusia primer dan dengan aktivasi diferensial jalur signaling MAP-kinase.[11]

TEGDMA penginduksi apoptosis ditemukan dalam sejumlah penelitian untuk dikaitkan dengan stres oksidatif melalui pembentukan Reactive Oxygen Species (ROS). Peningkatan ROS pada cel lines diikuti oleh penipisan glutathione intaseluler (GSH), agen pereduksi alami utama yang terlibat dalam detoksifikasi seluler dan pemeliharaan keseimbangan redoks. Para peneliti mendukung bahwa penipisan GSH disertai oleh peroksidasi lipid dan kerusakan mitokondria, yang ditunjukkan oleh kerusakan potensial membran signifikan dikurangi oleh turunan larutan tocoferol (vitamin E) dan mitokondria. Efek ini secara

oleh CCCP (carbonylcyanide mchlorophenylhydrazone), sebuah pelepasan fosforilasi oksidatif pada peroksidasi lipid dan kebocoran LDH. [11]

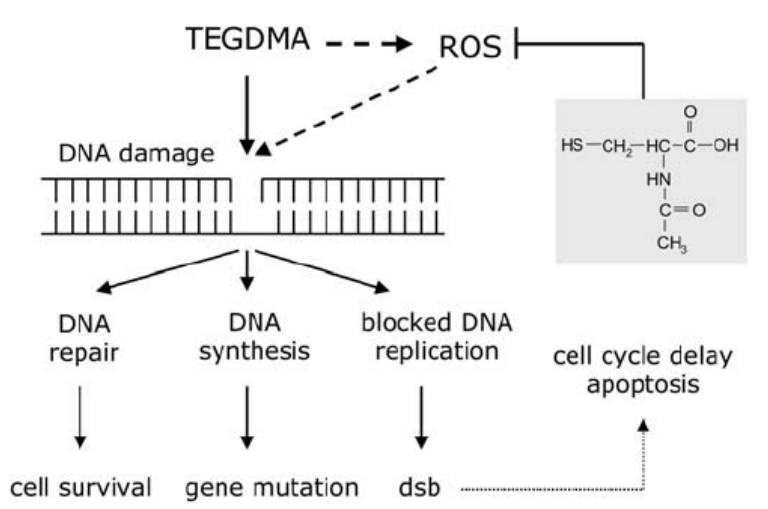

Gambar 3. Gambaran induksi genotoksisitas pada sel mamalia dengan triethylene glycol dimethacrylate (TEGDMA) dan respon selular ${ }^{12}$

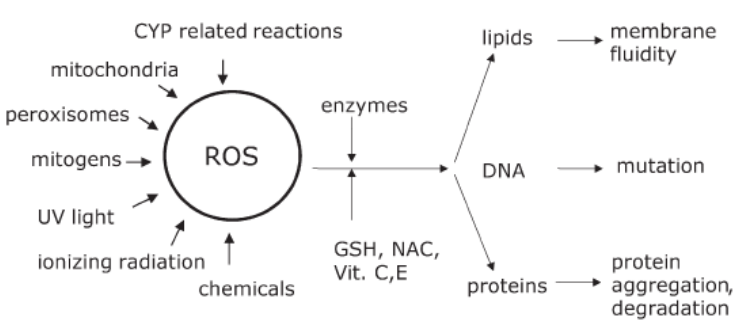

Gambar 4. Produksi reactive oxygen species (ROS) dan respon sel [12]

$\mathrm{H} 2 \mathrm{O} 2$ yang dihasilkan pada
tingkat mitokondria dapat
berinteraksi dengan mitokondria $\mathrm{Fe}^{2+}$
yang menghasilkan pembentukan
$\mathrm{OH}$ yang kemudian berinteraksi
dengan asam lemak dan memulai
peroksidasi lipid. Karena peroksidasi
lipid dalam sel yang terpapar
TEGDMA terjadi setelah penipisan
GSH secara lengkap, H2O2 yang
diproduksi dalam mitokondria tidak
dapat diambil oleh GSH dan dapat

Tienneke Riana Septiwidyati, Elza Ibrahim Auerkari Program Magister Oral Biologi, Fakultas Kedokteran Gigi, Universitas Indonesia Departemen Oral Biologi, Fakultas Kedokteran Gigi, Universitas Indonesia 
menghasilkan $\mathrm{OH}$ dan peroksidasi lipid.[13]

ROS secara terus-menerus diproduksi di mitokondria. Mitokondria memiliki sistem perlindungan antioksidan termasuk GSH dan enzim seperti superoksida dismutase dan glutathione peroxydase. Dengan demikian, GSH mitokondria memainkan peran utama dalam pertahanan melawan stres oksidatif. Namun, mitokondria sepenuhnya bergantung pada sitosol untuk menyuplai, akibatnya, penipisan GSH sitosol yang berkepanjangan akhirnya mengakibatkan penipisan GSH mitokondria sehingga mengganggu proses detoksifikasi ROS mitokondria dengan generasi $\mathrm{OH}$ yang diikuti oleh peroksidasi lipid.[13]

TEGDMA juga dilaporkan menyebabkan kerusakan genotoksik yang signifikan. Telah ditemukan dapat meningkatkan jumlah mikronukleus dan meningkatkan degradasi DNA yang berasal dari jaringan kelenjar ludah dan limfosit, seperti yang ditunjukkan dalam uji komet. Namun, induksi micronuclei secara jelas dapat dihilangkan oleh fraksi mikrosomal (S9) dari hati tikus, yang menunjukkan bahwa metabolit TEGDMA tidak dapat menyebabkan kerusakan genotoksik. Antioksidan juga mampu mengurangi induksi TEGDMA mikronukleus. TEGDMA dilaporkan menyebabkan penghilangan ekstensif urutan nukleotida pada gen hipoksantin-guanidin phosphoribosyltransferase (hprt) di V79 fibroblast paru hamster Cina, yang menunjukkan potensi klastogenik dari TEGDMA. Barubaru ini, telah dilaporkan bahwa TEGDMA mampu menyebabkan kerusakan DNA oksidatif, yang ditunjukkan pada generasi 8-oxoG, diikuti oleh aktivasi ATM kinase, yang dengan sendirinya mungkin mengaktifkan jalur yang mengarah ke apoptosis. Selain itu, dengan menggunakan teknologi microarray bahwa kerusakan sel yang diinduksi TEGDMA diikuti oleh induksi gen yang mengkode proses biologis, termasuk stres oksidatif, pertumbuhan sel, proliferasi dan morfologi, kematian sel, replikasi DNA, dan perbaikan. Gen yang paling diregulasi adalah GEM, KLHL24, DDIT4, TGIF, DUSP5 dan ATF3, yang terkait dengan pengaturan struktur sel, respon stres dan proliferasi sel, sedangkan transkrip yang paling banyak diatur adalah TXNIP yang mengatur keseimbangan redoks seluler. Sebagai konsekuensi dari kerusakan DNA, berbagai pola penundaan siklus sel (terutama dalam fase G2) telah dilaporkan pada berbagai cell line yang terpapar pada TEGDMA, untuk memungkinkan proses perbaikan DNA.[11]

\section{HEMA methacrylate) \\ (2-Hydroxy-ethyl-}

Banyak dilakukan, hal ini karena HEMA merupakan salah satu komponen yang paling umum dari dentinadhesives, berkisar antara 30-55\% dan memiliki peran penting selama proses impregnation dentin pada sistem adhesif. Dikarenakan afinitas airnya yang tinggi, memungkinkan 
HEMA mengalir ke jaringan kolagen dari matriks organik dentin, sehingga mendukung infiltrasi dan mencegah kolagen kolaps. Karena HEMA memiliki berat molekul rendah dan hidrofilisitas yang tinggi, maka HEMA juga dapat berdifusi di seluruh dentin residual dan mempengaruhi vitalitas odontoblas, mengubah pembelahan sel dan aktivitas fisiologis. Pelepasan HEMA dari dental komposit terpolimerisasi berkisar dari 1,5 - $8 \mathrm{mmol} / \mathrm{L}$.[11]

Efek sitotoksik HEMA ditemukan sangat sedikit jika dibandingkan dengan monomer lain. HEMA memberikan efek sitotoksik juga dikaitkan dengan stres oksidatif, yang ditunjukkan oleh produksi ROS dan penipisan glutathione intraseluler. Efek ini juga ditemukan berkurang dengan adanya antioksidan. Namun penelitian lain melaporkan bahwa produksi ROS yang diinduksi oleh HEMA mungkin tidak diikuti oleh penurunan GSH pada sel epitel gingiva manusia, karena penipisan GSH telah ditandai pada konsentrasi tinggi, sementara produksi ROS yang berlebihan tercatat juga pada konsentrasi yang lebih rendah.[11]

Kondisi redoks yang tidak seimbang yang disebabkan oleh HEMA lebih lanjut terkait dengan penundaan siklus sel dan apoptosis yang melibatkan aktivasi caspases-8, -9 dan -3. HEMA menginduksi apoptosis ditemukan terkait dengan aktivasi faktor nuklir kappa B (NF$\mathrm{kB}$ ), yang berperan protektif untuk melawan sitotoksisitas HEMA dan aktivasi MAP kinase diferensial, termasuk fosforilasi JNK dan p38. HEMA penginduksi apoptosis juga telah diusulkan sebagai mekanisme penting untuk pembangkitan dan persistensi reaksi hipersensitivitas pasien terhadap monomer ini.[11]

Dalam hal genotoksisitas, HEMA juga telah dilaporkan sebagai bahan kimia klastogenik dengan meningkatkan jumlah mikronuklei, efeknya berkurang setelah inaktivasi metabolik. Telah ditemukan juga untuk meningkatkan migrasi DNA dalam tes Comet. Efek ini diikuti oleh penundaan siklus sel, tetapi ditemukan berkurang dengan adanya antioksidan.[11]

\section{Basic Monomers BisGMA (2,2- \\ Bis[4-(2- hydroxy-3- methacryloxypropoxy) phenyl] propane) and UDMA (Urethane dimethacrylate)}

Secara umum, monomer aromatik BisGMA telah ditemukan sedikit lebih sitotoksik daripada monomer UDMA alifatik. BisGMA tidak mudah larut dalam air dan hanya tersedia dalam jumlah kecil dalam lingkungan hidrofilik. UDMA, yang telah sering digunakan saat ini untuk menggantikan BisGMA di banyak dental resin komposit karena fleksibilitas dan kekasarannya yang tinggi.[11]

Mengenai genotoksisitas, BisGMA dan UDMA juga telah ditemukan dapat meningkatkan jumlah mikronuklei dan efek ini untuk dikurangi dengan campuran S9, dengan cara yang sama seperti dengan TEGDMA dan HEMA. Migrasi DNA juga telah dilaporkan dalam tes Comet untuk monomer ini. Monomer resin dasar BisGMA dan UDMA, terdapat sekitar 70-75\% dari total matriks resin komposit, 
berkontribusi terhadap bahan-bahan sitotoksisitas dan genotoksisitas. Meskipun karakter hidrofobik mereka yang membatasi pelepasannya ke dalam lingkungan berair mereka mampu memberikan efek sitotoksik pada konsentrasi yang jauh lebih rendah dibandingkan dengan HEMA dan TEGDMA.[11]

\section{KESIMPULAN}

Monomer pada resin komposit dapat menyebabkan efek sitotoksik dan genotoksik pada konsentrasi yang relevan yang dilepaskan di rongga mulut. Monomer berperan pada peningkatan intraselular spesies oksigen reaktif dan penurunan konsentrasi glutasi sehingga menyebabkan kerusakan pada DNA. Dari beberapa penelitian dapat dibuat peringkat sitotoksisitas monomer dasar sebagai berikut, BisGMA> UDMA> TEGDMA >>> HEMA.

\section{DAFTAR PUSTAKA}

[1].Hertzberg IFaI. Cyto- and genotoxicity of dental resin composites in human gingival epithelium progenitor cells as assessed by the single cell gel electrophoresis (comet) assay [University of Oslo; 2017.

[2].Kenneth J. Anusavice CS, H. Ralph Rawls. Resin-Based Composites. In: H. RALPH RAWLS P, editor. Phillips Science of Dental Materials. 12 ed: Elsevier; 2012.

[3].Five Things You Need To Know About Bulk Fill Composite Resins. Dental Product Report: Bisco; 2017. p. 1-7.
[4].Kolle S. Genotoxicity and Carcinogenicity: BASF The Chemical Company; 2012.

[5].Kucklick TR. Assessing Biocompatibility: Pacific BioLabs; 2013.

[6].Dwi Ramadhani SPdDT. Deteksi Kerusakan DNA pada Sel Limfosit Darah Tepi Manusia dengan Teknik Tes Komet. Buletin Alara 2013;15:53-61.

[7].Gharsalli T. Comet Assay on Toxicogenetics; Several Studies in Recent Years on Several Genotoxicological Agents. Journal of Environmental \& Analytical Toxicology 2016;06(06).

[8].Tadin A, Galic N, Mladinic M, et al. Genotoxicity in gingival cells of patients undergoing tooth restoration with two different dental composite materials. Clin Oral Investig 2014;18(1):87-96.

[9].Taubock TT, Marovic D, Zeljezic $\mathrm{D}$, et al. Genotoxic potential of dental bulk-fill resin composites. Dent Mater 2017;33(7):788-95.

[10].Visalli G, Baluce B, La Maestra $\mathrm{S}$, et al. Genotoxic damage in the oral mucosa cells of subjects carrying restorative dental fillings. Arch Toxicol 2013;87(1):179-87.

[11]. Bakopoulou A, Papadopoulos T, Garefis P. Molecular toxicology of substances released from resin-based dental restorative materials. Int $\mathrm{J}$ Mol Sci 2009;10(9):3861-99.

[12].Schweikl H, Spagnuolo G, Schmalz G. Genetic and cellular toxicology of dental resin monomers. J Dent Res 2006;85(10):870-7. 
[13].Mathieu Lefeuvre WA, Michel Goldberg, Lena Stanislawski. TEGDMA induces mitochondrial damage and oxidative stress in human gingival fibroblasts. Biomaterials 2005;26(25):513037. 